\title{
A biblioteca em realidade virtual como um ambiente colaborativo
}

The virtual reality library as a collaborative environment



A realidade virtual ( $R V$ ) tem-se mostrado uma tecnologia que pode ampliar o espectro de acesso à informação. Desde um simples programa para computador, que permite a interação através de ambientes tridimensionais, até programas mais sofisticados, como por exemplo, simuladores de vôo, que proporcionam um envolvimento e grau de realismo jamais vistos. Por meio de vários recursos, aliados a essa tecnologia, evidenciamos o acesso à informação por meio de Ambientes Virtuais Colaborativos (AVC) em que indivíduos em lugares geograficamente distantes, podem compartilhar informações e o próprio ambiente. Nesse contexto, o ambiente biblioteca mostrou-se propício para a incorporação de AVC, considerando que mediante simulações em realidade virtual, o usuário pode pegar um livro na prateleira, folhear, escolher os assuntos e interagir com conteúdos e outros sujeitos, tudo isso sem dispensar a ajuda e o papel do bibliotecário, que pode ser representado no ambiente tridimensional por avatares e desenvolver a função de facilitador. Com o objetivo de propor a aplicação da tecnologia de realidade virtual em ambientes de bibliotecas acessadas pela Internet, desenvolvemos uma proposta de uma biblioteca em realidade virtual como um ambiente colaborativo. Para o desenvolvimento da pesquisa, utilizou-se como metodologia, a revisão da literatura disponível sobre o tema em apreço e a identificação dos tipos de bibliotecas disponíveis na Internet. Após a coleta de dados bibliográficos, verificou-se a ausência de Bibliotecas em Realidade Virtual como Ambiente Colaborativo e a falta de consenso sobre o significado de uma biblioteca em realidade virtual. Como resultados apresentamos um relato de estudo sobre a aplicação da RV em bibliotecas, destacando a importância de ambientes colaborativos no processo de geração e uso de informações para a construção coletiva de conhecimento, proporcionado pela utilização das tecnologias de Realidade Virtual, objeto de estudo desta pesquisa.

$$
\begin{array}{r}
\text { Andréa Toti Matos } \\
\text { Dissertação de Mestrado, } 2003 \\
\text { Faculdade de Filosofia e Ciências, } \\
\text { Universidade Estadual Paulista - UNESP, Campus de } \\
\text { Marília, São Paulo. } \\
\text { <atotimatos@uol.com.br> }
\end{array}
$$

PALAVRAS-CHAVE: Bibliotecas; internet. KEY WORDS: Libraries; internet. PALABRAS CLAVE: Bibliotecas; internet.

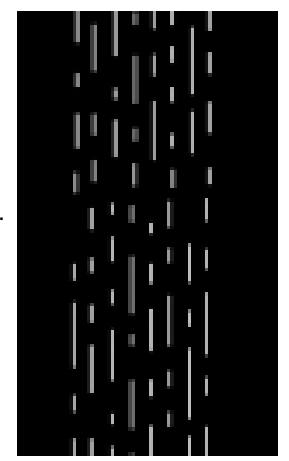

Recebido para publicação em 18/07/03. Aprovado para publicação em 28/08/03. 